\title{
Profile of and risk factors for poststroke cognitive impairment in diverse ethnoregional groups
}

Jessica W. Lo, MSc, John D. Crawford, PhD, David W. Desmond, PhD, Olivier Godefroy, MD, Hanna Jokinen, PhD, Simin Mahinrad, MD, Hee-Joon Bae, MD, Jae-Sung Lim, MD, Sebastian Köhler, PhD, Elles Douven, PhD, Julie Staals, MD, Christopher Chen, MD, Xin Xu, PhD, Eddie J. Chong, BA, Rufus O. Akinyemi, PhD, Rajesh N. Kalaria, FRCPath, Adesola Ogunniyi, FRCP, Mélanie Barbay, MD, Martine Roussel, PhD, Byung-Chul Lee, MD, Velandai K. Srikanth, PhD, Christopher Moran, PhD, Nagaendran Kandiah, FRCP, Russell J. Chander, BA, Behnam Sabayan, MD, J. Wouter Jukema, MD, Susanna Melkas, MD, Timo Erkinjuntti, MD, Henry Brodaty, MD, Régis Bordet, MD, Stéphanie Bombois, MD, Hilde Hénon, MD, Darren M. Lipnicki, PhD, Nicole A. Kochan, PhD, and Perminder S. Sachdev, MD, for the Stroke and Cognition (STROKOG) Collaboration

Neurology ${ }^{\circledR}$ 2019;93:e2257-e2271. doi:10.1212/WNL.0000000000008612

\section{Abstract \\ Objective}

To address the variability in prevalence estimates and inconsistencies in potential risk factors for poststroke cognitive impairment (PSCI) using a standardized approach and individual participant data (IPD) from international cohorts in the Stroke and Cognition Consortium (STROKOG) consortium.

\section{Methods}

We harmonized data from 13 studies based in 8 countries. Neuropsychological test scores 2 to 6 months after stroke or TIA and appropriate normative data were used to calculate standardized cognitive domain scores. Domain-specific impairment was based on percentile cutoffs from normative groups, and associations between domain scores and risk factors were examined with 1-stage IPD meta-analysis.

\section{Results}

In a combined sample of 3,146 participants admitted to hospital for stroke (97\%) or TIA (3\%), $44 \%$ were impaired in global cognition and 30\% to $35 \%$ were impaired in individual domains 2 to 6 months after the index event. Diabetes mellitus and a history of stroke were strongly associated with poorer cognitive function after covariate adjustments; hypertension, smoking, and atrial fibrillation had weaker domain-specific associations. While there were no significant differences in domain impairment among ethnoracial groups, some interethnic differences were found in the effects of risk factors on cognition.

\section{Conclusions}

This study confirms the high prevalence of PSCI in diverse populations, highlights common risk factors, in particular diabetes mellitus, and points to ethnoracial differences that warrant attention in the development of prevention strategies.

\author{
Correspondence \\ Dr. Sachdev \\ p.sachdev@unsw.edu.au
}

From the Centre for Healthy Brain Ageing (J.W.L., J.D.C., R.J.C., H.B., D.M.L., N.A.K., P.S.S.), University of New South Wales, Sydney, Australia; Department of Neurology and Laboratory of
Functional Neurosciences (O.G., M.B., M.R.), University Hospital of Amiens, France; Clinical Neurosciences (H.J., S.M., T.E.), Neurology, University of Helsinki and Helsinki University Hospital,
Finland; Department of Internal Medicine (S.M.), Gerontology and Geriatrics Section, and Department of Cardiology (J.W.J.), Leiden University Medical Center, the Netherlands; Department of
Neurology (S.M., B.S.), Feinberg School of Medicine, Northwestern University, Chicago, IL; Department of Neurology (H.J.B.), Seoul National University School of Medicine, Seoul National
University Bundang Hospital, Seongnam; Department of Neurology (J.-S.L., B.-C.L.), Hallym University Sacred Heart Hospital, Anyang, Republic of Korea; Department of Psychiatry and
Neuropsychology (S.K., E.D.), School for Mental Health and Neuroscience, Alzheimer Center Limburg, Maastricht University; Department of Neurology (J.S.), Cardiovascular Research Institute
Maastricht, Maastricht University Medical Center, the Netherlands; Memory Aging and Cognition Centre (C.C., X.X., E.J.C.), Department of Pharmacology, Yong Loo Lin School of Medicine, National
University of Singapore; Centre for Population Health Sciences (X.X.), Lee Kong Chian School of Medicine, Nanyang Technological University, Singapore; Neuroscience and Ageing Research Unit
(R.O.A., A.O.), Institute for Advanced Medical Research and Training, and Department of Medicine (R.O.A.), College of Medicine, University of Ibadan, Nigeria; Institute of Neuroscience (R.N.K.),
Newcastle University, Newcastle Upon Tyne, UK; Peninsula Clinical School (V.K.S., C.M.), Central Clinical School, Monash University; Department of Aged Care (C.M.), Alfred Health, Melbourne,
Australia; National Neuroscience Institute (N.K., R.J.C.); Duke-NUS Medical School (N.K.), Singapore; Dementia Collaborative Research Centre (H.B., P.S.S.), University of New South Wales, Sydney,
Australia; and University of Lille (R.B., S.B., H.H.), Inserm, CHU Lille, U1171-Degenerative \& Vascular Cognitive Disorders, France. 


\section{Glossary}

AF = atrial fibrillation; CHF = congestive heart failure; DSM-IV = Diagnostic and Statistical Manual of Mental Disorders, 4th edition; IPD = individual participant data; MI = myocardial infarction; NEMESIS = North East Melbourne Stroke Incidence Study; PROSPER = Prospective Study of Pravastatin in the Elderly at Risk; PSCI = poststroke cognitive impairment; SAM = Helsinki Stroke Aging Memory Study; STROKDEM = Study of Factors Influencing Post-Stroke Dementia; STROKOG = Stroke and Cognition Consortium.

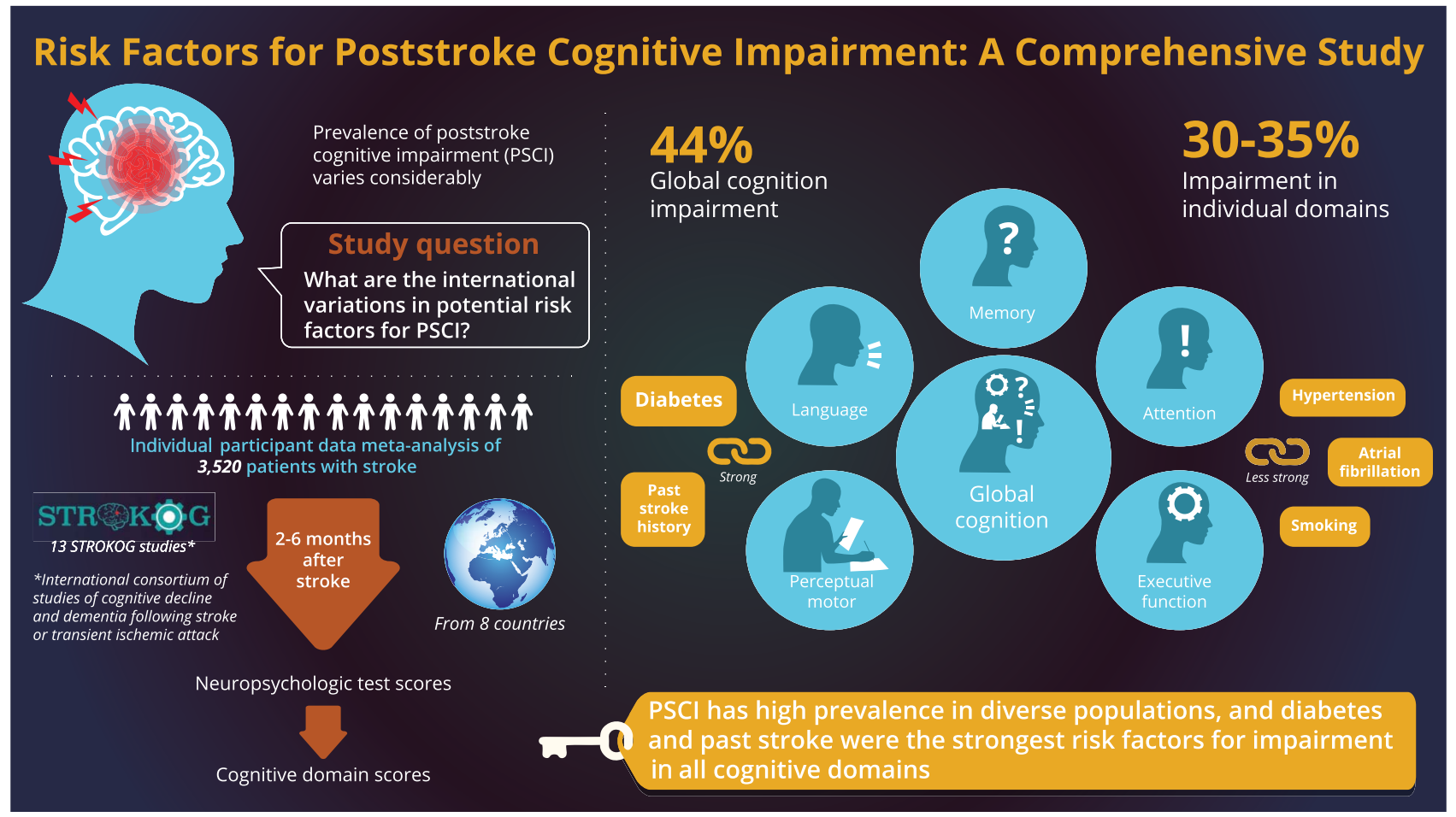

doi:10.1212/WNL.0000000000008612

Copyright (c) 2019 American Academy of Neurology

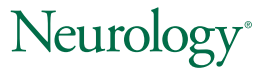

While poststroke cognitive impairment (PSCI) is mild in many stroke survivors, numerous studies have reported a prevalence of dementia in poststroke cases that varies from $7.4 \%$ in a population-based study of first stroke to $41.3 \%$ in hospital-based cases of recurrent stroke. ${ }^{1}$ The prevalence may differ by geographic region, diagnostic criteria, and methods of assessment. Because the severity of cognitive impairment in poststroke patients is on a continuum, however, it is arguably more meaningful to use a standardized continuous measure to examine cognitive impairment rather than the diagnosis of dementia. ${ }^{2}$ Because of the heterogeneity of stroke and its effects on cerebral function, the cognitive profile of poststroke dementia is understandably complex. There is evidence that some cognitive domains, in particular complex attention, working memory, and frontal executive function, are affected early in vascular dementia. ${ }^{3}$ Poststroke dementia, however, is also associated with language and visuospatial dysfunction, even though individuals with severe language impairment are often excluded from detailed investigations. ${ }^{4}$ In addition, studies of cognitive profile have largely been conducted in white, non-Hispanic populations, and it is uncertain whether the same pattern is seen in Asian and African populations.

The clinical determinants of PSCI remain incompletely understood. While older age and low levels of education have consistently emerged as risk factors, ${ }^{5}$ various other putative risk factors have been inconsistently reported, including risk factors for cerebrovascular disease (e.g., hypertension, diabetes mellitus, atrial fibrillation $[\mathrm{AF}]$, smoking), prior pathology (e.g., previous stroke, Alzheimer disease), APOE genotype, stroke features, and lesion characteristics. ${ }^{6}$ The variability of the findings has prevented a consensus from being reached on the most relevant factors in predicting the development of poststroke dementia. ${ }^{7}$ The Stroke and Cognition Consortium (STROKOG), an international consortium of studies of cognitive decline and dementia after stroke or TIA, offers an opportunity to address the inconsistencies in prevalence estimates and potential risk factors for PSCI. ${ }^{8}$ This article presents a comprehensive profile of the cognitive performance of patients 2 to 6 months after stroke or TIA and explores the associations between a variety of risk factors and impairment in cognitive function. We hypothesized that the prevalence of 
PSCI will be high across different geographical regions but will vary across different ethnoracial groups. We also hypothesized that PSCI affects different cognitive domains equally and that vascular risk factors for stroke are also risk factors for PSCI independently of the occurrence of stroke.

\section{Methods}

\section{Inclusion criteria}

STROKOG member studies with detailed neuropsychological assessments 2 to 6 months after stroke/TIA that agreed to share data in 2016 were included. Studies were required to have recruited a control group, provided data for an appropriate comparison group (e.g., from a representative local study), or provided standardized test scores that were adjusted for sex, age, and education using an appropriate comparison group. A flow diagram showing studies that were included is given in appendix F1 available from Dryad (doi.org/10.5061/dryad.m517990).

\section{Contributing studies}

Thirteen studies from Africa (1), Asia (4), Australia (2), Europe (5), and the United States (1) contributed data (table 1). Three studies enrolled patients with TIA (clinically diagnosed and confirmed by a neurologist), and 9 studies excluded participants with preexisting dementia (i.e., previously diagnosed or based on the Informant Questionnaire on Cognitive Decline in the Elderly at recruitment; an overview of study recruitment strategies and inclusion and exclusion criteria is provided in appendixes T1 and T3 available from Dryad, doi. org/10.5061/dryad.m517990). All studies except the North East Melbourne Stroke Incidence Study (NEMESIS; community cohort) and Prospective Study of Pravastatin in the Elderly at Risk (PROSPER; randomized controlled trial) were hospital-based observational studies of consecutively admitted patients with stroke or TIA (table 1). The Study of Factors Influencing Post-Stroke Dementia (STROKDEM) was the only study to exclude participants with dementia after the index stroke. Not including PROSPER, 5 studies

Table 1 Contributing studies

\begin{tabular}{|c|c|c|c|c|c|c|}
\hline Study & Abbreviation & Country & No. ${ }^{a}$ & $\begin{array}{l}\text { Year } \\
\text { study began }\end{array}$ & $\begin{array}{l}\text { Type of study/ } \\
\text { population }\end{array}$ & $\begin{array}{l}\text { Time between } \\
\text { index event and } \\
\text { assessment, mo }\end{array}$ \\
\hline $\begin{array}{l}\text { Bundang Vascular Cognitive } \\
\text { Impairment Cohort }\end{array}$ & Bundang VCl & Korea & 660 & 2007 & $\begin{array}{l}\text { Observational/ } \\
\text { hospital }\end{array}$ & 3 \\
\hline $\begin{array}{l}\text { Cognition and Affect After Stroke: } \\
\text { Prospective Evaluation of Risks }\end{array}$ & CASPER & The Netherlands & 250 & 2013 & $\begin{array}{l}\text { Observational/ } \\
\text { hospital }\end{array}$ & 3 \\
\hline Cognitive Outcome After Stroke & COAST & Singapore & 326 & 2009 & $\begin{array}{l}\text { Observational/ } \\
\text { hospital }\end{array}$ & $3-6$ \\
\hline $\begin{array}{l}\text { Cognitive Function After Stroke } \\
\text { Nigeria }\end{array}$ & $\begin{array}{l}\text { CogFAST- } \\
\text { Nigeria }\end{array}$ & Nigeria & 143 & 2010 & $\begin{array}{l}\text { Observational/ } \\
\text { hospital }\end{array}$ & 3 \\
\hline $\begin{array}{l}\text { Epidemiologic Study of the Risk of } \\
\text { Dementia After Stroke }\end{array}$ & EpiUSA & United States & 453 & 1988 & $\begin{array}{l}\text { Observational/ } \\
\text { hospital }\end{array}$ & 3 \\
\hline $\begin{array}{l}\text { Groupe de Réflexion pour } \\
\text { l'evaluation Cognitive Vasculaire } \\
\text { Study }\end{array}$ & GRECogVASC & France & 200 & 2010 & $\begin{array}{l}\text { Observational/ } \\
\text { hospital }\end{array}$ & 6 \\
\hline $\begin{array}{l}\text { Korean-Vascular Cognitive } \\
\text { Impairment Harmonization } \\
\text { Standards Study }\end{array}$ & K-VCIHS & Korea & 353 & 2007 & $\begin{array}{l}\text { Observational/ } \\
\text { hospital }\end{array}$ & 3 \\
\hline $\begin{array}{l}\text { North East Melbourne Stroke } \\
\text { Incidence Study }\end{array}$ & NEMESIS & Australia & 99 & 1998 & $\begin{array}{l}\text { Observational/ } \\
\text { community }\end{array}$ & 3 \\
\hline $\begin{array}{l}\text { National Neuroscience Institute } \\
\text { Study }\end{array}$ & NNI & Singapore & 185 & 2011 & $\begin{array}{l}\text { Observational/ } \\
\text { hospital }\end{array}$ & $2-6$ \\
\hline $\begin{array}{l}\text { Prospective Study of Pravastatin in } \\
\text { the Elderly at Risk }\end{array}$ & PROSPER & $\begin{array}{l}\text { Ireland, } \\
\text { Scotland, the } \\
\text { Netherlands }\end{array}$ & 130 & 1993 & $\begin{array}{l}\text { Randomised } \\
\text { clinical trial/ } \\
\text { primary care }\end{array}$ & $1-6$ \\
\hline $\begin{array}{l}\text { Helsinki Stroke Aging Memory } \\
\text { Study }\end{array}$ & SAM & Finland & 409 & 1993 & $\begin{array}{l}\text { Observational/ } \\
\text { hospital }\end{array}$ & 3 \\
\hline Sydney Stroke Study & SSS & Australia & 167 & 1997 & $\begin{array}{l}\text { Observational/ } \\
\text { hospital }\end{array}$ & $3-6$ \\
\hline $\begin{array}{l}\text { Study of Factors Influencing Post- } \\
\text { Stroke Dementia }\end{array}$ & STROKDEM & France & 145 & 2011 & $\begin{array}{l}\text { Observational/ } \\
\text { hospital }\end{array}$ & 6 \\
\hline
\end{tabular}

a Sample size used for the Stroke and Cognition Consortium (STROKOG) project, not of the study itself. For study details, see appendixes T1 through T3 available from Dryad (doi.org/10.5061/dryad.m517990). 
recruited their own control group of stroke-free volunteers without serious illnesses from the surrounding community. Other studies provided data or calculated standardized test scores on the basis of population-based studies that consisted of local stroke-free volunteers, except for STROKDEM, which used published local normative data (brief descriptions of each study and control group details are given in appendixes T2 and T4 available from Dryad). All studies provided individual participant data (IPD) except PROSPER and Helsinki Stroke Aging Memory Study (SAM), an observational study from Helsinki, both of which conducted in-house analyses using a protocol prepared for this project.

\section{Standard protocol approvals, registrations, and patient consents}

Procedures of the consortium have been approved by the University of New South Wales Human Research Ethics Committee (reference HC14359). All studies had ethics approval from local institutional review boards.

\section{Demographics and medical history}

Patient demographic variables included age, sex, and education level, with education converted into a 4-category variable (details on how education level data were harmonized are given in appendix T5 available from Dryad, doi.org/10.5061/ dryad.m517990). Most cohorts consisted predominantly of 1 ethnoracial group; for the harmonization of ethnicity, we classified white participants from all Western studies as white but kept separate each of the Asian and African American/ Nigerian subgroups (details on how ethnicity data were harmonized are given in appendix T6 available from Dryad). For the baseline stroke/TIA event (the index event), 6 studies included ischemic stroke only; other studies included a small number of TIAs and/or hemorrhagic strokes. Regarding stroke characteristics, we examined stroke subtype and stroke laterality. Those characteristics were determined on the basis of the results of routine structural brain imaging, typically CT scans for older studies and MRI for more recent studies, considered alone or in combination with the results of the neurologic examination and other medical workups. Stroke subtype was coded into 6 categories, with 5 ischemic stroke subtypes-large artery, small vessel, cardioembolic, other determined (ischemic), and undetermined (ischemic) - and hemorrhagic stroke (subtypes of hemorrhagic stroke were not included due to small numbers; details on the original classification used in each study and how they were harmonized are given in appendix T7 available from Dryad). Stroke laterality refers to cerebral strokes only and was coded as left hemisphere, right hemisphere, or bilateral (brainstem/cerebellar strokes were not included). Each study recorded differing sets of putative risk factors, with important cardiovascular risk factors such as a history of hypertension, type 2 diabetes mellitus, AF, past stroke (before the index event), and smoking (past or present), collected by most studies. A subset of studies collected data on congestive heart failure ( $\mathrm{CHF}$ ), angina, and myocardial infarction (MI), but no other risk factors were collected by $>2$ studies. Medical conditions were as noted in medical records except for in SAM, which used specific clinical criteria (appendix T2 available from Dryad).

\section{Statistical methods}

\section{Cognitive profile and prevalence of impairment}

To harmonize the different neuropsychological tests conducted by all studies, we calculated standardized scores, adjusted for age, sex, and education. This approach, described in a review of harmonization methods as standardization by the use of T scores, ${ }^{9}$ closely parallels the common neuropsychological practice of interpreting test scores using standardized values obtained from normative data provided in test manuals. First, we standardized raw test scores into $z$ scores based on the control group of the study (details regarding the method used for calculating $z$ scores in each study are given in appendix A2.2 available from Dryad, doi.org/10.5061/dryad. m517990). ${ }^{9,10}$ The $z$ scores were adjusted for sex, age, and education with a regression method. We then assigned each test to 1 of 5 cognitive domains: attention and processing speed (attention), memory, language, perceptual motor, or frontal executive function (executive function), according to common practice $^{11}$ and previous work. ${ }^{12}$ We calculated domain $z$ scores as standardized means of all test $z$ scores in a domain; the global cognition score was the standardized mean of the 5 cognitive domains. Methodologic details and the list of neuropsychological tests used in each domain in each study are available from Dryad (appendixes A2 and T10).

Participants with $z$ scores $<6.68$ th percentiles (equivalent to $<1.5$ SDs for normally distributed scores) in the comparison group were considered impaired in a domain. The 2.28th percentile ( 2 SDs) was used as a more stringent criterion for severe impairment. For studies without comparison group data, cut points were estimated from the averages from studies with available data (appendix A3 available from Dryad, doi. org/10.5061/dryad.m517990). We calculated overall proportions of impairment by stroke subtype, side of stroke, and ethnoracial groups, and differences between subgroups were explored with $\chi^{2}$ tests.

In addition, we used mixed-effects logistic regression models to explore the association between ethnicity and impairment, with study as a random effect. Only ethnoracial groups represented by $\geq 2$ studies were included in these analyses to ensure that more general conclusions about ethnoracial groups could be drawn.

\section{Vascular risk factors and cognitive function}

The relationship between risk factors and cognitive function was examined with 1-stage IPD meta-analysis using linear mixed models, with study as the random effect. ${ }^{13}$ Each model includes global cognition or 1 of the 5 cognitive domain scores as the outcome variable, with adjustment for sex, age (in years), and education (in 4 categories). In the first step, each risk factor was modeled separately as the independent variable. In the second step 
and main set of analyses, risk factors (hypertension, diabetes mellitus, smoking, AF, smoking, past stroke) were included together in a single multivariable model. In the third step, stroke subtype was added, and the Baron and Kenny ${ }^{14}$ approach was used to examine possible mediation by stroke subtype (methodological details are given in appendix A4.1 available from Dryad, doi.org/10.5061/ dryad.m517990).

We did not adjust for other covariates (e.g., APOE) because of missing data for many studies. Collinearity was checked by examining the correlation between risk factors and calculating the variance inflation factor for each independent variable in the model. The main analysis (step 2) was examined in addition with the 2-stage IPD meta-analysis to produce forest plots and the heterogeneity measure $I^{2} .^{15}$ Linear regression models were used to produce effect estimates of risk factors in each study, and results were combined by use of randomeffects models. Further analyses were conducted with both stroke and control groups. We examined whether the effects of risk factors differed between these groups by including interactions (stroke status $\times$ risk factor) in the models (appendix A4.2 available from Dryad, doi.org/10.5061/dryad. m517990).

\section{All analyses}

We did not include NEMESIS and PROSPER in the combined sample because they were not hospital-based studies. Therefore, for all patients in the combined sample, neuropsychological assessments were performed 2 to 6 months after stroke (refer to the flowchart in appendix F1 available from Dryad, doi.org/10.5061/dryad.m517990). STROKDEM was not included in the profile analysis because it excluded participants with dementia after the index stroke. Because SAM did not provide IPD and conducted analyses independently, we combined those summary results with ours using meta-analytic methods. ${ }^{13}$ For all analyses, global cognition was considered the primary measure for cognitive function, and the significance level was assessed at the 0.05 level ( 2 sided); the 5 domains were secondary measures, and Bonferroni correction was applied for multiple comparisons across cognitive domains ( $\alpha$ [adjusted] $=0.01$ ). All analyses were performed with Stata 14.1 (StataCorp, College Station, TX). The Preferred Reporting Items for a Systematic Review and Meta-Analysis IPD checklist was used for reporting. ${ }^{16}$

\section{Data availability}

Anonymized data will be shared on request from any qualified investigator.

\section{Results}

\section{Sample characteristics}

Maximum sample size was 3,520 from 13 studies with $61 \%$ male, average age 67.0 years $(\mathrm{SD}=11.1)$, and $44 \%$ white (see table 2 for other patient characteristics in the combined sample and in individual studies). Most patients (92\%) had had an ischemic stroke, $4.7 \%$ TIA, and $1.8 \%$ hemorrhagic stroke (table 3; additional data on stroke and risk factor characteristics are available in appendix T8 from Dryad, doi. org/10.5061/dryad.m517990).

\section{Cognitive profile and prevalence of impairment}

For the combined sample $(\mathrm{n}=2,698)$, mean $z$ scores for the 5 domains were similar at approximately $-1 \mathrm{SD}$, and mean global cognition was -1.5 SDs; $44 \%$ of patients were impaired in global cognition, and between $30 \%$ and $35 \%$ were impaired across the 5 domains 2 to 6 months after stroke or TIA (table 4). Figure 1 shows the percentage of impairment in each domain in each study, with full results available from Dryad (appendix T11, doi.org/10.5061/dryad.m517990). Studies not included in the combined sample had the lowest proportions of impairment ( $1 \%-19 \%$ across domains). When the more stringent criterion of the 2.28th percentile was used, the proportion of impairment was $\approx 10 \%$ less across all domains, with a similar pattern of impairment observed across studies. If we take out the 3 studies $(n=1,198)$ that did not exclude preexisting dementia, the overall proportion of impairment was $42 \%$ in global cognition and $25 \%$ to $35 \%$ in individual domains, with no more than a $5 \%$ difference compared to the percentages observed in the combined sample.

Dementia was originally diagnosed with a variety of methods, including DSM-IV and Vascular Behavioral and Cognitive Disorders criteria (summaries available in appendixes T9 and T12 from Dryad, doi.org/10.5061/dryad.m517990), in 3\% to $26 \%$ of patients and mild cognitive impairment in $26 \%$ to $67 \%$ in studies that were included in the combined sample. For studies with no missing domain scores, $37 \%$ to $61 \%$ had impairment in $\geq 2$ domains and $56 \%$ to $79 \%$ had impairment in $\geq 1$ domains. For each study, the proportion of those clinically diagnosed with dementia or mild cognitive impairment was comparable to the proportion of patients impaired in $\geq 1$ domains (results available from Dryad, appendix T12).

Proportions of impairment were significantly greater in left hemisphere stroke compared to right hemisphere stroke in global cognition $(p=0.004)$, memory $(p<0.001)$, language $(p<0.001)$, and executive function $(p<0.001)$ (results showing the proportions of impairment in each domain by side of stroke are available from Dryad, appendix T13, doi. org/10.5061/dryad.m517990). Impairment was greater in right hemisphere stroke compared to left hemisphere stroke in perceptual motor function, but the statistical significance was borderline ( $p=0.026$; results available from Dryad, appendix T13). In terms of stroke subtype, strokes related to small vessel disease etiology had lower proportions of impairment compared to other subtypes in global cognition $(p<$ 0.001 ) and all domains except memory; impairment proportions were greater for cardioembolic strokes vs others in global cognition $(p=0.007)$, language, and executive function 
Table 2 Characteristics of participants with stroke/TIA from contributing studies

\begin{tabular}{|c|c|c|c|c|c|c|c|c|c|c|c|c|c|c|}
\hline & $\begin{array}{l}\text { Bundang } \\
\text { VCl }\end{array}$ & CASPER & COAST & $\begin{array}{l}\text { CogFAST- } \\
\text { Nigeria }\end{array}$ & Epi USA & GRECogVASC & K-VCIHS & NEMESIS & NNI & PROSPER & SAM & SSS & STROKDEM & All studies \\
\hline No. & 660 & 250 & 326 & 143 & 453 & 200 & 353 & 99 & 185 & 130 & 409 & 167 & 145 & 3,520 \\
\hline Age, y & $67.7(10.5)$ & $67.5(12)$ & $59.8(11)$ & $60.3(9.5)$ & 71.9 (8.3) & $65.1(10.3)$ & $64.5(13)$ & 70.5 (14) & $57.7(11)$ & $75.4(3.4)$ & 70.7 (7.7) & 72.1 (9.1) & $63.3(13)$ & $67.0(11.1)$ \\
\hline Age range, y & $22-91$ & $42-91$ & $23-94$ & $45-84$ & $59-96$ & $41-81$ & $12-93$ & $28-98$ & $30-85$ & $70-82$ & $55-85$ & $49-86$ & $25-87$ & $12-98$ \\
\hline Male, n (\%) & $414(63)$ & $161(64)$ & $229(70)$ & $81(57)$ & $215(47)$ & $121(61)$ & $216(61)$ & $58(59)$ & $128(69)$ & 71 (55) & 202 (49) & $104(62)$ & $92(63)$ & 2,092 (59) \\
\hline Education, y & $10.0(5.4)$ & NA & $7.7(4.3)$ & $9.3(5.6)$ & $10.1(4.9)$ & $10.3(3.0)$ & NA & $9.7(2.3)$ & $9.3(3.3)$ & $15.4(2.15)^{\star}$ & $9.2(4.1)$ & $10.6(3.1)$ & $11.3(4.0)$ & $9.5(4.4)$ \\
\hline $\begin{array}{l}\text { Less than high } \\
\text { school } \\
\text { completion, } \\
\text { n (\%) }\end{array}$ & $327(50)$ & $102(41)$ & $199(61)$ & $80(56)$ & $243(54)$ & $150(75)$ & $286(81)^{c}$ & $68(69)$ & $71(39)$ & NA & $225(55)$ & $118(71)$ & $88(61)$ & $1,957(58)$ \\
\hline $\begin{array}{l}\text { High school } \\
\text { completion, } \\
\text { n (\%) }\end{array}$ & $125(19)$ & $82(33)$ & $60(18)$ & $16(11)$ & $104(23)$ & $19(10)$ & $N A^{c}$ & $17(17)$ & 71 (39) & NA & $35(9)$ & $10(6)$ & $18(12)$ & $557(16)$ \\
\hline $\begin{array}{l}\text { Technical or } \\
\text { college } \\
\text { diploma, } \\
\text { n (\%) }\end{array}$ & $45(6.8)$ & $17(6.8)$ & $51(16)$ & $26(18)$ & $39(9)$ & $17(9)$ & $67(19)^{\mathrm{C}}$ & $14(14)$ & $38(21)$ & NA & $96(23)$ & $24(14)$ & $16(11)$ & $450(13)$ \\
\hline $\begin{array}{l}\text { Bachelor's } \\
\text { degree and } \\
\text { above, n (\%) }\end{array}$ & $163(25)$ & 47 (19) & $16(5)$ & $21(15)$ & $67(15)$ & $14(7)$ & $N A^{c}$ & 0 & $4(2)$ & NA & $53(13)$ & $15(9)$ & $23(16)$ & $423(12)$ \\
\hline Ethnicity $^{a}$ & Korean & White & $\begin{array}{l}\text { Singaporean } \\
\text { Chinese }^{a}\end{array}$ & Nigerian & $\begin{array}{l}\text { 43\% White; } \\
44 \% \text { African } \\
\text { American }^{\mathrm{b}}\end{array}$ & White & Korean & White & $\begin{array}{l}\text { Singaporean } \\
\text { Chinese }^{a}\end{array}$ & White & White & White & White & $\begin{array}{l}\text { 44\% White; 29\% Korean; } \\
11 \% \text { Chinese; } 6 \% \text { African } \\
\text { American; } 4 \% \text { Nigerian }\end{array}$ \\
\hline
\end{tabular}

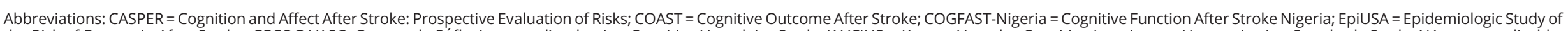

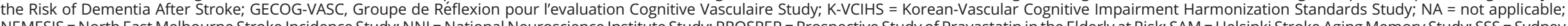

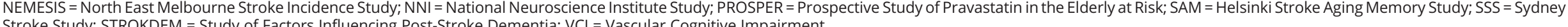
Stroke Study; STROKDEM = Study of Factors I untuencing Post-Stroke Dent

Figures are number (percent) or mean (SD) unless specified. Details on the coding of education are available from Dryad (appendix T5, doi.org/10.5061/dryad.m517990).

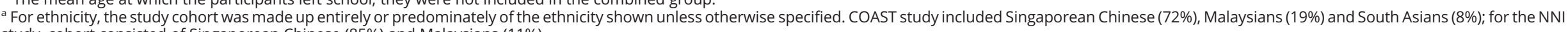
study, cohort consisted of Singaporean Chinese $(85 \%)$ and Malaysians (11\%).

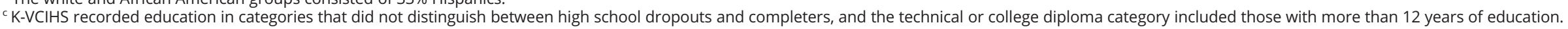


Table 3 Risk factors and stroke event of participants with stroke/TIA from each study

\begin{tabular}{|c|c|c|c|c|c|c|c|c|c|c|c|c|c|c|}
\hline & $\begin{array}{l}\text { Bundang } \\
\text { VCl }\end{array}$ & CASPER & COAST & $\begin{array}{l}\text { CogFAST- } \\
\text { Nigeria }\end{array}$ & Epi USA & GRECogVASC & K-VCIHS & NEMESIS & NNI & PROSPER & SAM & sSS & STROKDEM & All studies \\
\hline No. & 660 & 250 & 326 & 143 & 453 & 200 & 353 & 99 & 185 & 130 & 409 & 167 & 145 & 3,520 \\
\hline \multicolumn{15}{|l|}{ Medical history, n (\%) } \\
\hline Hypertension & $477(72)$ & $180(72)$ & $233(71)$ & 132/141 (94) & $331(73)$ & $125(63)$ & $222(63)$ & $57(58)$ & $143(77)$ & $71(55)$ & $199(49)$ & $\begin{array}{l}94 / 159 \\
(59)\end{array}$ & $78(54)$ & $\begin{array}{l}2,611 / 3,508 \\
(74)\end{array}$ \\
\hline Diabetes mellitus & $186(28)$ & $37(15)$ & $129(40)$ & $34 / 139(24)$ & $156(34)$ & $45(23)$ & $114(32)$ & $16(16)$ & $60(32)$ & $18(14)$ & $96(24)$ & $\begin{array}{l}23 / 157 \\
(15)\end{array}$ & $17(12)$ & $\begin{array}{l}931 / 3,505 \\
(27)\end{array}$ \\
\hline Atrial fibrillation & $99(15)$ & $24(9.8)$ & $35(11)$ & $5 / 137(4)$ & $\begin{array}{l}58 / 451 \\
(13)\end{array}$ & $24(12)$ & $54(15)$ & NC & $28(15)$ & NC & $\begin{array}{l}80 / 408 \\
(20)\end{array}$ & $\begin{array}{l}38 / 156 \\
(24)\end{array}$ & $16(11)$ & $\begin{array}{l}437 / 3,019 \\
(14)\end{array}$ \\
\hline History of past stroke & $73(11$ & $16(6.4)$ & $\begin{array}{l}64 / 326 \\
(20)^{\mathrm{a}}\end{array}$ & 18/136 (13) & $\begin{array}{l}109 / 451 \\
(24)\end{array}$ & $15(8)$ & $64(18)$ & 0 & $28(15)$ & $28(22)$ & $77(19)$ & $\begin{array}{l}22 / 156 \\
(14)\end{array}$ & $14(10)$ & $\begin{array}{l}528 / 3,498 \\
(15)\end{array}$ \\
\hline Smoking (ever) & $247(45)$ & $186(74)$ & $133(41)$ & $28 / 136(21)$ & $\begin{array}{l}262 / 448 \\
(58)\end{array}$ & $72(36)$ & $161(46)$ & $60(60)$ & $79(43)$ & $92(71)$ & $\begin{array}{l}222 / 399 \\
(56)\end{array}$ & $\begin{array}{l}94 / 160 \\
(59)\end{array}$ & $31(21)$ & $\begin{array}{l}1,667 / 3,382 \\
(49)\end{array}$ \\
\hline $\begin{array}{l}\text { Index event (at } \\
\text { baseline), } \mathrm{n}(\%)\end{array}$ & & b & & $\mathrm{b}$ & & & & & & $\mathrm{b}$ & & & & b \\
\hline Ischemic stroke & $660(100)$ & $233(93)$ & $254(78)$ & $116(81)$ & $453(100)$ & $180(90)$ & $\begin{array}{l}353 \\
(100)\end{array}$ & $88(89)$ & $\begin{array}{l}185 \\
(100)\end{array}$ & $43(33)$ & $409(100)$ & $135(81)$ & 144 (99) & $3,253(92)$ \\
\hline Hemorrhagic stroke & 0 & $15(6)$ & 0 & $16(11)$ & 0 & $20(10)$ & 0 & $11(11)$ & 0 & $2(1.5)$ & 0 & 0 & $1(0.7)$ & $65(1.8)$ \\
\hline TIA & 0 & 0 & $72(22)$ & 0 & 0 & 0 & 0 & 0 & 0 & $60(46)$ & 0 & $32(19)$ & 0 & $164(4.7)$ \\
\hline
\end{tabular}

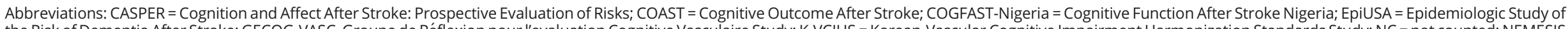

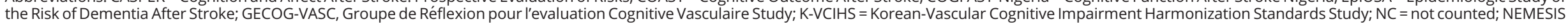

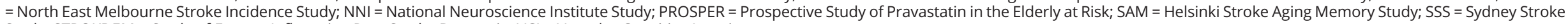
Study; STROKDEM = Study of Factors Influencing Post-Stroke Dementia; VCI = Vascular Cognitive Impairment

Figures are number (percent) if there are no missing values. For those with missing values, number/sample with available data (percent) is shown instead.

a Includes TIA.

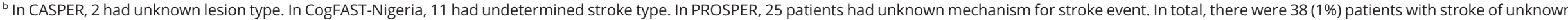
type. 


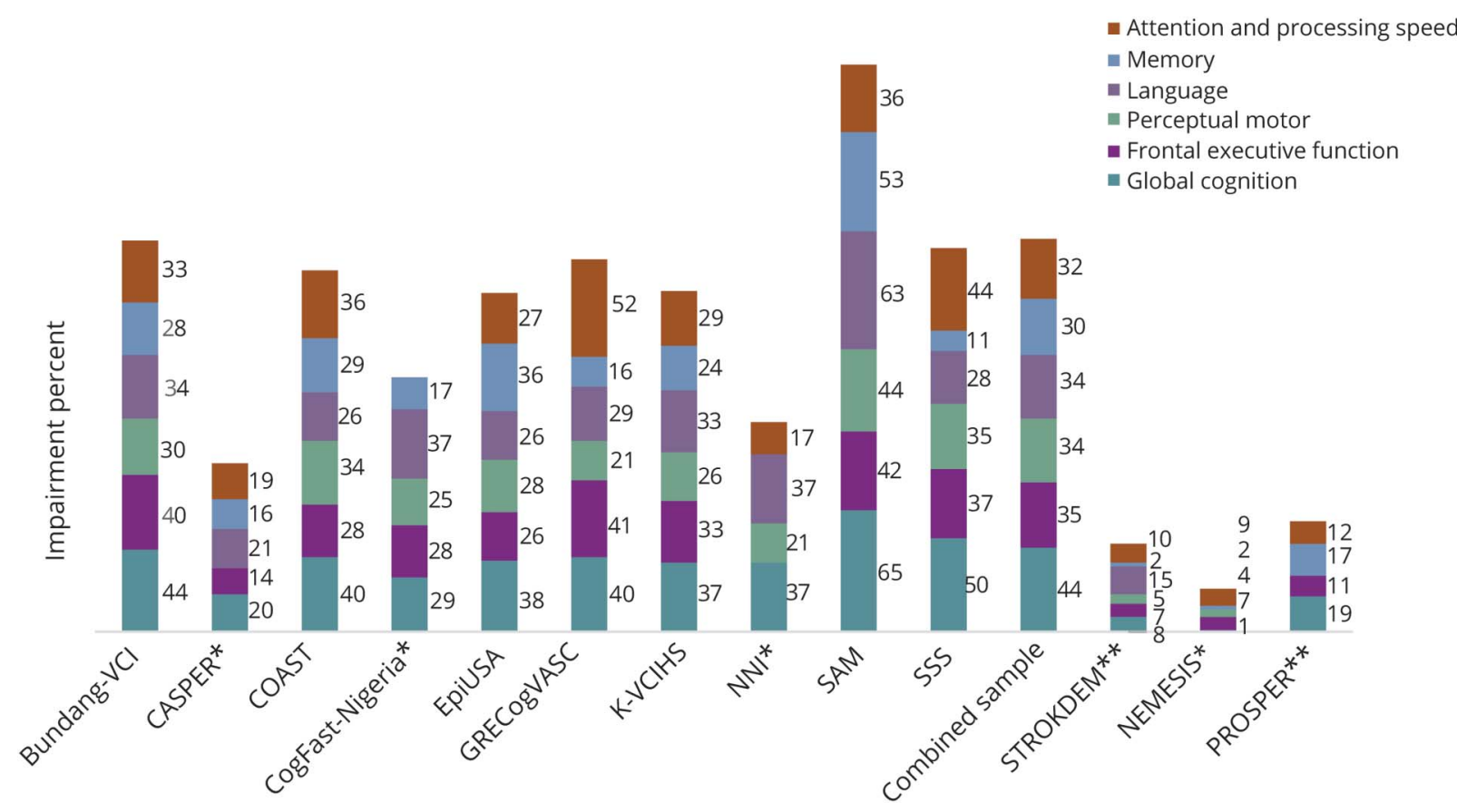

Each column does not add up to 100\%. Impairment is based on the 6.68th percentile. COAST = Cognitive Outcome After Stroke; EpiUSA = Epidemiologic Study of the Risk of Dementia After Stroke; GRECogVASC = Groupe de Réflexion pour l'evaluation Cognitive Vasculaire Study; K-VCIHS = Korean-Vascular Cognitive Impairment Harmonization Standards Study; SAM = Helsinki Stroke Aging Memory Study; SSS = Sydney Stroke Study; VCI = Vascular Cognitive Impairment. *Studies with missing domain score. **Studies not included in the combined sample.

(results available from Dryad, appendix T13). There was no significant difference in impairment between ischemic and hemorrhagic strokes ( $p=0.34$ for global cognition).

Regarding ethnoracial groups, we observed the highest proportion of global impairment in African Americans (48\%, 1 study), followed by whites (47\%, 5 studies), Koreans (45\%, 2 studies), Nigerians (40\%, 1 study), and Singaporean Chinese (35\%, 2 studies; results showing the proportions of impairment by ethnoracial groups are available from Dryad, appendix T14, doi.org/10.5061/dryad.m517990). Pairwise comparison showed significant differences between Koreans and Chinese and between whites and Chinese in certain domains (results available from Dryad, appendix T14). However, mixed models (before covariate adjustments) did not reveal any significant relationships between ethnoracial groups and impairment.

\section{Vascular risk factors and cognitive function}

Diabetes mellitus was strongly associated with poorer performance in global cognition and in all domains when examined independently (table 5) and after adjustment for other risk factors $(-0.47 \mathrm{SD} ; p<0.001$ in global cognition; full results available from Dryad, appendix T15, doi.org/10.5061/ dryad.m517990). Similarly, a history of stroke was associated with poorer global cognition $(-0.45 \mathrm{SD} ; p<0.001)$ and

Table 4 Cognitive domain profile for the combined sample

\begin{tabular}{|c|c|c|c|c|c|c|}
\hline Combined sample & $\begin{array}{l}\text { Attention and } \\
\text { processing speed }\end{array}$ & Memory & Language & $\begin{array}{l}\text { Perceptual } \\
\text { motor }\end{array}$ & $\begin{array}{l}\text { Frontal executive } \\
\text { function }\end{array}$ & $\begin{array}{l}\text { Global } \\
\text { cognition }\end{array}$ \\
\hline z Score & $-0.98(1.80)$ & $-0.84(1.45)$ & $-1.00(1.51)$ & $-1.03(1.70)$ & $-1.10(1.72)$ & $-1.47(1.91)$ \\
\hline $\begin{array}{l}\text { Impaired (6.68th } \\
\text { percentile), } \mathrm{n}(\%)\end{array}$ & $907 / 2,841(32)$ & $873 / 2,903(30)$ & $1,044 / 3,086(34)$ & $871 / 2,577$ (34) & $977 / 2,825$ (35) & $1,381 / 3,116(44)$ \\
\hline $\begin{array}{l}\text { Very impaired (2.28th } \\
\text { percentile), } n(\%)\end{array}$ & $669 / 2,841(24)$ & $519 / 2,903(18)$ & $723 / 3,086(23)$ & $544 / 2,577(21)$ & $741 / 2,825(26)$ & $995 / 3,116(32)$ \\
\hline
\end{tabular}

The $z$ scores with normal distributions are shown as mean (SD). The impairment figures are the number of participants impaired out of the number of participants with available data (e.g., who completed tests in a domain), with corresponding percent. Results on the cognitive profile for each study are available from Dryad (appendix T7, doi.org/10.5061/dryad.m517990). Combined sample includes 10 studies (excluding North East Melbourne Stroke Incidence Study [NEMESIS], Prospective Study of Pravastatin in the Elderly at Risk [PROSPER], and Study of Factors Influencing Post-Stroke Dementia [STROKDEM]). 
impairment in all domains except memory. Although the effects were smaller, hypertension was also associated with poorer global cognition, language, and executive function when examined independently, and it remained significantly related to global cognition after adjustment $(-0.16 \mathrm{SD} ; p=$ 0.02). Patients with AF had poorer global cognition, attention, and executive function after adjustment $(-0.26 \mathrm{SD} ; p=$ 0.005 for global). Past or current smoking was a significant risk factor for perceptual motor impairment $(-0.24 \mathrm{SD}$; $p=$ 0.001 ), but it was not significantly related to global cognition $(-0.13$ SD; $p=0.06)$.

When examined alone on the basis of 5 studies, CHF was strongly associated with poorer cognitive function in global cognition and in all domains (table 5), but it was not significant after adjustment for other risk factors (results available from Dryad, appendix T16, doi.org/10.5061/dryad. $\mathrm{m} 517990)$. On the basis of 4 studies, we found no significant association between angina or MI and cognition $(p=0.98$ and 0.91, respectively, for global cognition; table 5).

After further adjustment for stroke subtype, the results for all risk factors remained unchanged except for AF, the effect of which on global cognition changed from $-0.26 \mathrm{SD}(p=$ $0.005)$ to nearly zero (0.02; $p=0.90$; results available from Dryad, appendix T17, doi.org/10.5061/dryad.m517990). Because AF is associated with larger infarcts, we tested for the mediation effects of cardioembolic stroke vs other subtypes. Results showed that conditions for full mediation were met, with the effect of $\mathrm{AF}$ on cognition reduced to nearly zero $(-0.03 ; p=0.84$; the steps and results of the mediation analysis are available from Dryad, appendix A4.1).

We further explored 2-way interactions among risk factors and between a risk factor and demographic factors, and none was significant (results available in appendix T18 from Dryad, doi.org/10.5061/dryad.m517990). However, there were significant interactions with ethnoracial groups: diabetes mellitus, past stroke, and smoking were associated with poorer performance in global cognition, attention, and memory, respectively, in Koreans compared to whites $(-0.74$ vs -0.32 SD; $p=0.013$ for diabetes mellitus and global cognition). The association of smoking with executive function was weaker in Chinese compared to Koreans ( $p=$ 0.0008), and the association of AF with memory was weaker in Chinese compared to whites $(p=0.005$; full results available from Dryad, appendix T19).

In 2 separate sensitivity analyses that first excluded 104 (4\%) patients with TIA and then excluded 3 studies that did not exclude patients with preexisting dementia $(n=1,198)$, the results were very similar to our key findings, with effect sizes changing by $<5 \%$ in either direction in the first analysis and $15 \%$ in the second. In the analysis that included controls to examine whether the effects of risk factors were the same in stroke and control groups, none of the interaction terms was significant.
Heterogeneity among studies was low in most of the metaanalyses $\left(I^{2}=0 \%-49 \%\right)$; for AF and past stroke, heterogeneity was moderate and significant in certain domains $\left(I^{2}=\right.$ $50 \%-63 \%$; $p<0.05$; for global cognition, refer to figure 2 ; the rest of the forest plots are available from Dryad, appendix F2, doi.org/10.5061/dryad.m517990). However, heterogeneity was reduced in the analysis of AF with stroke subtype as an additional adjustment: $I^{2}$ was reduced from $54.2 \%(p=0.016)$ to $26.8 \%(p=0.20)$ for global cognition. For a history of stroke, we conducted a sensitivity analysis by removing studies with effect sizes that deviated $>1$ SD from the pooled effect. This did not change the significant association of past stroke with poorer cognition.

\section{Discussion}

This article presents a large-scale examination by an international consortium of the effects of stroke on cognitive function using IPD and a standardized approach to characterizing cognitive impairment. While we did not generate dementia diagnoses because too few studies had item-level data available on instrumental activities of daily living scales, we have instead presented a comprehensive characterization of cognitive performance in patients after stroke.

Our results showed that impairment was common and generalized, with proportions of impaired patients varying from $30 \%$ to $35 \%$ in each cognitive domain, even though other studies showed a preponderance of disturbance in the domains of attention/processing speed and frontal executive function. ${ }^{4}$ Although memory impairment was not a salient feature in our cohort, in the absence of biomarkers, potential contributions from Alzheimer disease and other neurodegenerative pathologies to cognitive impairment in our cohort cannot be dismissed.

We have shown that patients with stroke related to small vessel disease etiology had significantly less impairment than patients with other stroke subtypes 2 to 6 months after stroke. Smaller stroke volume in those with stroke related to small vessel disease compared to other etiologies may be associated with a lower proportion of impairment, and the use of detailed imaging data would be beneficial in further investigating this finding in future studies. Cerebral small vessel disease often causes stroke, however, and a review has suggested that associated small vessel disease may increase the effect of stroke on cognitive function, ${ }^{17}$ an effect that might be observed with longer follow-up.

As expected, there was a greater proportion of impairment in patients with left hemisphere stroke vs those with right hemisphere stroke in the language domain. In addition, greater impairment in patients with left hemisphere stroke in memory and executive function can be explained by the fact that many of the tests included in those domains are verbal 
Table 5 Independent effect of risk factor on cognitive domain and global cognition scores

\begin{tabular}{|c|c|c|c|c|c|c|c|}
\hline & & $\begin{array}{l}\text { Attention and processing } \\
\text { speed }\end{array}$ & Memory & Language & Perceptual motor & $\begin{array}{l}\text { Frontal executive } \\
\text { function }\end{array}$ & Global cognition \\
\hline Risk factor & $\begin{array}{l}\text { Maximum No. of } \\
\text { studies }\end{array}$ & $\begin{array}{l}\text { Effect size }(95 \% \mathrm{Cl}) ; \\
p \text { value }\end{array}$ & $\begin{array}{l}\text { Effect size }(95 \% \mathrm{Cl}) ; \\
p \text { value }\end{array}$ & $\begin{array}{l}\text { Effect size }(95 \% \mathrm{Cl}) ; \\
p \text { value }\end{array}$ & $\begin{array}{l}\text { Effect size }(95 \% \mathrm{Cl}) \text {; } \\
p \text { value }\end{array}$ & $\begin{array}{l}\text { Effect size }(95 \% \mathrm{Cl}) \text {; } \\
p \text { value }\end{array}$ & $\begin{array}{l}\text { Effect size }(95 \% \mathrm{Cl}) \text {; } \\
p \text { value }\end{array}$ \\
\hline Hypertension & 11 & $-0.15(-0.29,-0.02) ; 0.023$ & $-0.09(-0.19,0.02) ; 0.11$ & $\begin{array}{l}-0.18(-0.29,-0.08) \\
0.001\end{array}$ & $\begin{array}{l}-0.17(-0.31,-0.04) \\
0.011\end{array}$ & $\begin{array}{l}-0.18(-0.31,-0.06) \\
0.004\end{array}$ & $\begin{array}{l}-0.24(-0.38,-0.11) \\
0.001\end{array}$ \\
\hline Diabetes mellitus & 11 & $-0.46(-0.61,-0.32) ;<0.001$ & $\begin{array}{l}-0.25(-0.35,-0.14) \\
<0.001\end{array}$ & $\begin{array}{l}-0.25(-0.35,-0.14) \\
<0.001\end{array}$ & $\begin{array}{l}-0.36(-0.49,-0.22) \\
<0.001\end{array}$ & $\begin{array}{l}-0.33(-0.47,-0.20) \\
<0.001\end{array}$ & $\begin{array}{l}-0.53(-0.67,-0.40) \\
<0.001\end{array}$ \\
\hline Smoking (ever) & 11 & $-0.06(-0.21,0.09) ; 0.42$ & $\begin{array}{l}-0.11(-0.22,-0.002) \\
0.046\end{array}$ & $0.01(-0.11,0.13) ; 0.86$ & $\begin{array}{l}-0.21(-0.35,-0.08) \\
0.002\end{array}$ & $0.01(-0.12,0.14) ; 0.88$ & $-0.11(-0.26,0.03) ; 0.13$ \\
\hline Atrial fibrillation & 11 & $-0.26(-0.44,-0.08) ; 0.005$ & $-0.02(-0.16,0.13) ; 0.82$ & $-0.06(-0.20,0.09) ; 0.42$ & $-0.13(-0.31,0.05) ; 0.15$ & $\begin{array}{l}-0.22(-0.40,-0.05) \\
0.014\end{array}$ & $-0.22(-0.40,-0.03) ; 0.02$ \\
\hline $\begin{array}{l}\text { History of past } \\
\text { stroke }\end{array}$ & 11 & $-0.51(-0.68,-0.33) ;<0.001$ & $\begin{array}{l}-0.18(-0.31,-0.05) \\
0.009\end{array}$ & $\begin{array}{l}-0.28(-0.42,-0.14) \\
<0.001\end{array}$ & $\begin{array}{l}-0.38(-0.54,-0.21) \\
<0.001\end{array}$ & $\begin{array}{l}-0.36(-0.53,-0.20) \\
<0.001\end{array}$ & $\begin{array}{l}-0.50(-0.67,-0.33) \\
<0.001\end{array}$ \\
\hline CHF & 5 & $-0.53(-0.91,-0.16) ; 0.006$ & $\begin{array}{l}-0.35(-0.60,-0.10) \\
0.008\end{array}$ & $\begin{array}{l}-0.46(-0.77,-0.15) ; \\
0.004\end{array}$ & $\begin{array}{l}-0.46(-0.78,-0.14) \\
0.005\end{array}$ & $\begin{array}{l}-0.48(-0.79,-0.18) \\
0.002\end{array}$ & $\begin{array}{l}-0.62(-0.99,-0.25) \\
0.001\end{array}$ \\
\hline Angina & 4 & $-0.01(-0.28,0.27) ; 0.97$ & $0.06(-0.12,0.25) ; 0.51$ & $-0.10(-0.29,0.16) ; 0.56$ & $0.04(-0.21,0.29) ; 0.76$ & $-0.08(-0.32,0.15) ; 0.50$ & $-0.004(-0.27,0.26) ; 0.98$ \\
\hline MI & 4 & $-0.05(-0.32,0.23) ; 0.74$ & $0.004(-0.23,0.23) ; 0.97$ & $-0.06(-0.28,0.16) ; 0.57$ & $-0.02(-0.27,0.23) ; 0.88$ & $-0.07(-0.30,0.17) ; 0.58$ & $-0.02(-0.28,0.25) ; 0.91$ \\
\hline
\end{tabular}

Abbreviations: $\mathrm{CHF}=$ congestive heart failure; $\mathrm{Cl}$, confidence interval; $\mathrm{MI}=$ myocardial infarction.

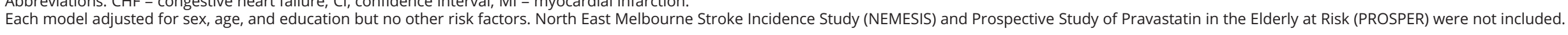


Figure 2 Forest plots of effect of risk factors on cognitive function in global cognition

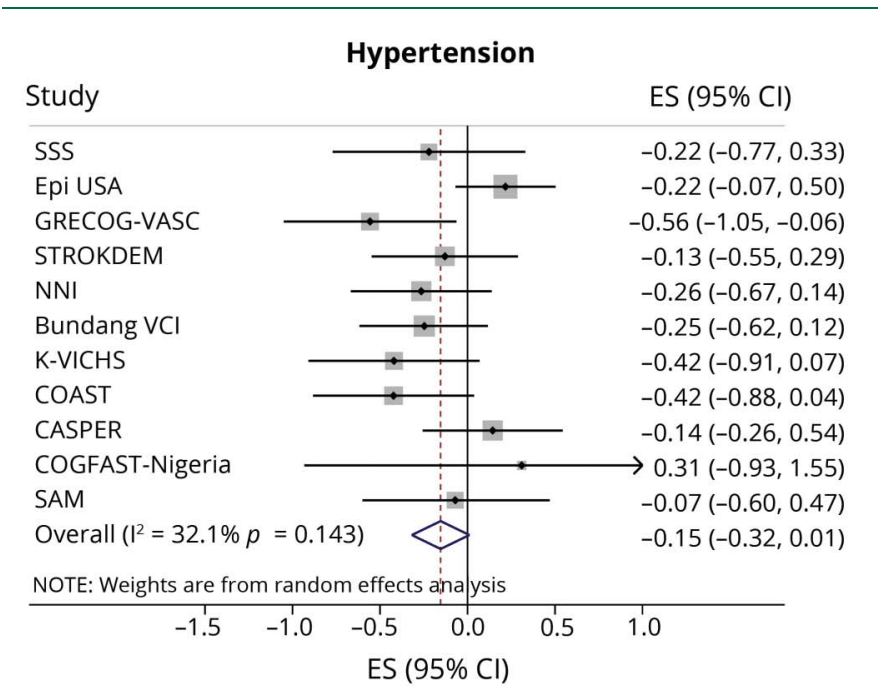
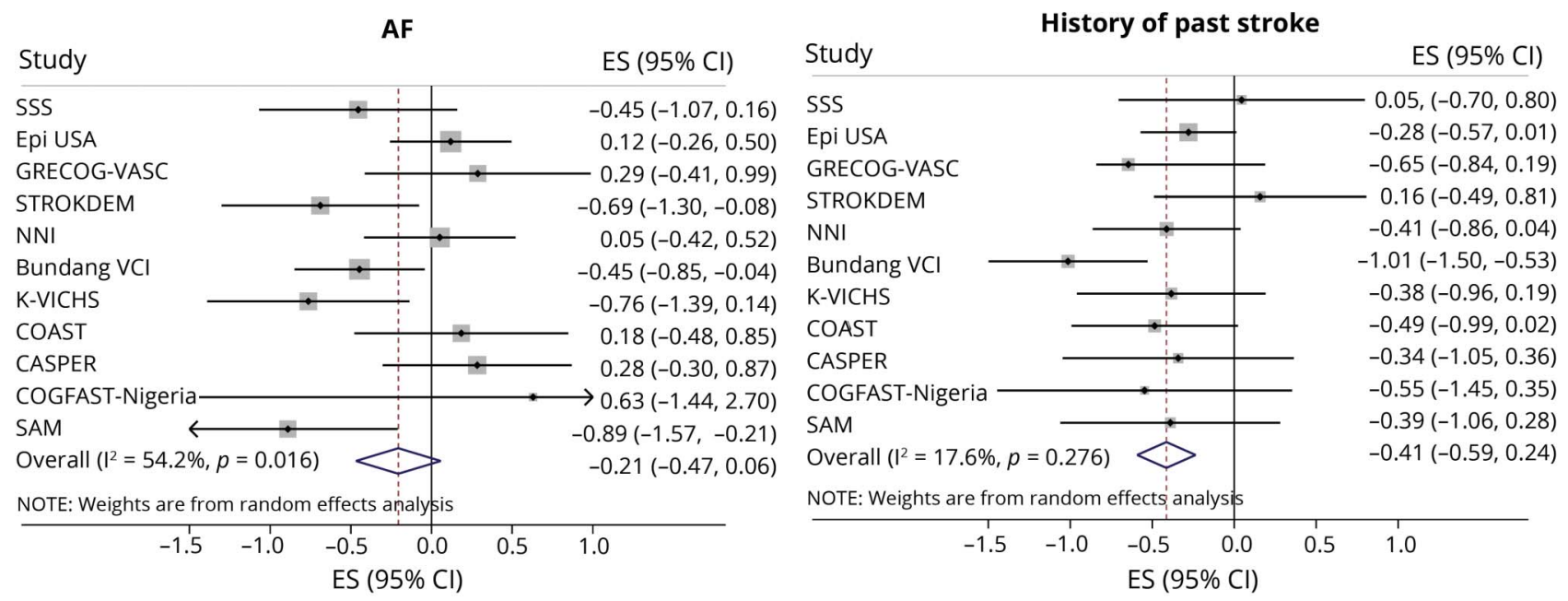

ES $(95 \% \mathrm{Cl})$

Study

Diabetes

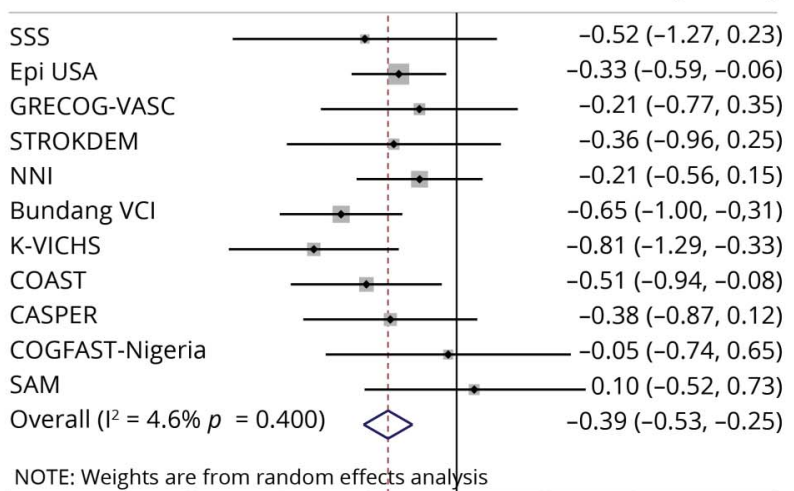

NOTE: Weights are from random effects analysis

$$
\begin{array}{cccccc}
-1.5 & -1.0 & -0.5 & 0.0 & 0.5 & 1.0 \\
& & & E S(95 \% \mathrm{Cl}) & &
\end{array}
$$

\section{History of past stroke}

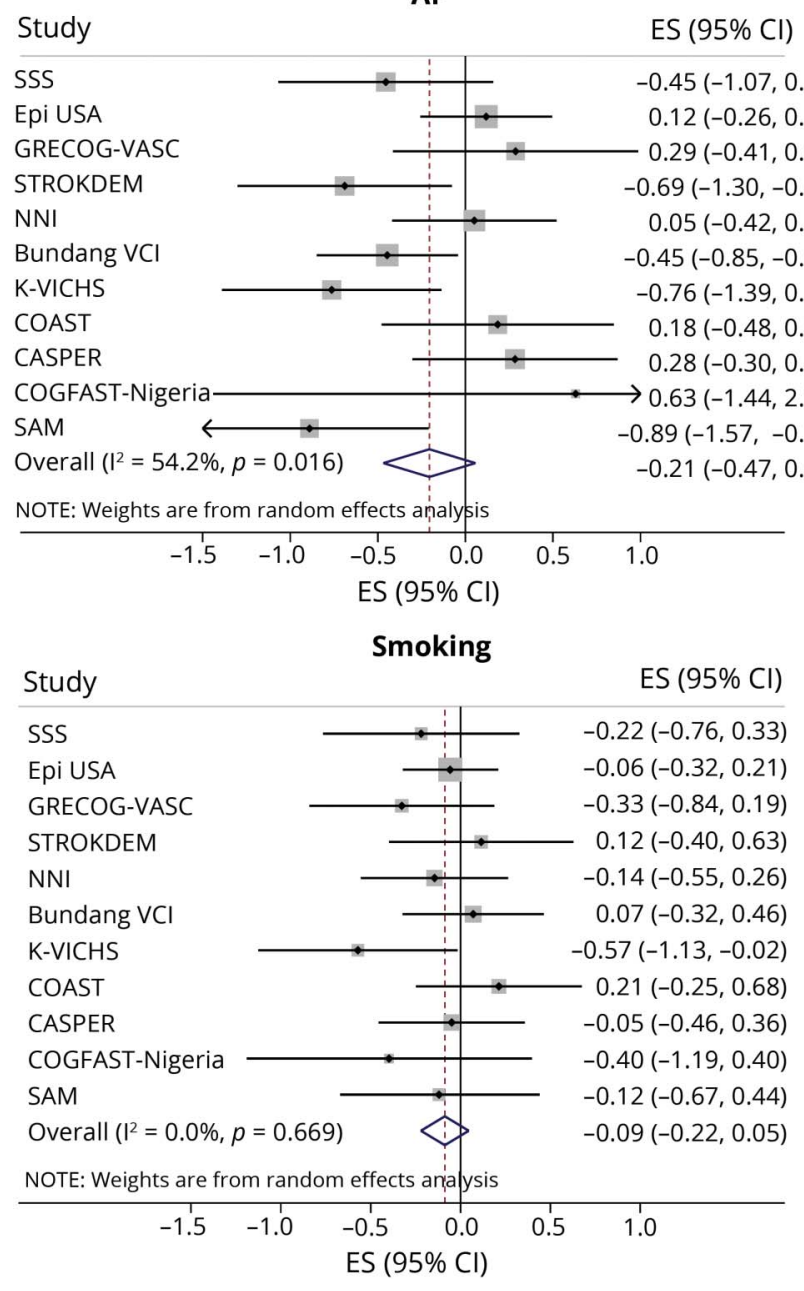

These 2-stage meta-analyses were used to examine the degree of variability across studies. For pooled effect sizes (ESs), refer to results from the 1-stage meta-analyses presented in table 5 (for global cognition) and data available from Dryad (appendix T15, doi.org/10.5061/dryad.m517990, for results in the 5 domains). CASPER = Cognition and Affect After Stroke: Prospective Evaluation of Risks; Cl = confidence interval; COAST = Cognitive Outcome After Stroke; COGFAST-Nigeria = Cognitive Function After Stroke Nigeria; EpiUSA = Epidemiologic Study of the Risk of Dementia After Stroke; GECOG-VASC = Groupe de Réflexion pour l'evaluation Cognitive Vasculaire Study; K-VCIHS = Korean-Vascular Cognitive Impairment Harmonization Standards Study; NEMESIS = North East Melbourne Stroke Incidence Study; NNI = National Neuroscience Institute Study; PROSPER = Prospective Study of Pravastatin in the Elderly at Risk; SAM = Helsinki Stroke Aging Memory Study; SSS = Sydney Stroke Study; STROKDEM = Study of Factors Influencing Post-Stroke Dementia; VCI = Vascular Cognitive Impairment. 
such as the Rey Auditory Verbal Learning Test and the verbal fluency test.

Our results did not reveal any significant differences in domain impairment among ethnoracial groups, a finding that may have been influenced by the small number of studies that included certain nonwhite groups. The inclusion of additional nonwhite cohorts will be necessary for future studies to examine inter-ethnoracial differences in the prevalence and potential causes of PSCI.

Our study confirms previous reports that a history of stroke is one of the strongest predictors of cognitive decline. ${ }^{2}$ Interestingly, we also found that diabetes mellitus was a strong and significant risk factor for impairment in all domains. A previous review noted the association between diabetes mellitus and vascular cognitive impairment, although the magnitude of effect $(-0.5 \mathrm{SD}$ in our analysis) was not described. ${ }^{8}$

Hypertension is a leading risk factor for stroke, and current evidence has shown that hypertension in midlife is associated with an increased risk of dementia. ${ }^{18,19}$ However, the evidence on the effects of hypertension later in life is less clear. ${ }^{20}$ Our study showed a significant association between hypertension and poorer global cognition, but the associations with the individual domains, although consistently negative, did not reach statistical significance. Because our study is cross-sectional, we were unable to assess potential differential effects of midlife and late-life hypertension or to examine the effect of the duration of hypertension on cognition.

A 2015 review found that current smokers compared with those who had never smoked showed a $38 \%$ increased risk of vascular dementia. ${ }^{21}$ Our results showed that smoking was negatively associated with perceptual motor performance, which agrees with a review that suggested that the effect of smoking may be domain specific. ${ }^{8}$ While we combined current and past smokers in our analysis, further studies should examine current vs past vs never smokers and the number of cigarettes smoked.

Recent studies have shown that $\mathrm{AF}$ is associated with a higher risk of cognitive impairment in both stroke and nonstroke populations. ${ }^{22}$ Our study showed that AF may be a risk factor for cognitive impairment, but its effects were explained by stroke subtype, namely the occurrence of cardioembolic stroke, which tends to more severe. This is consistent with the increased risk of cardioembolic strokes in patients with AF.

A recent meta-analysis reported coronary heart disease to be associated with an increased risk of cognitive impairment or dementia. ${ }^{23}$ However, we did not find evidence of an association between coronary artery disease, as manifested by angina and MI, and cognition. Our data showed that CHF was associated with impaired cognition, although not independently of other risk factors, but the power to test this association was limited.

While some patients with TIA may have truly transient symptomatology, TIA is associated with increased risk of stroke and concomitant cognitive impairment. Neuroimaging studies have shown that a clinically diagnosed TIA may be associated with preexisting brain infarct and other ischemic changes. ${ }^{24}$ We note that only 2 studies in the combined analyses included patients with TIA (4\%); at the same time, the diagnoses of TIA may differ across our studies due to different definitions used and the quality of information available. We addressed these issues by performing a sensitivity analysis that showed that the results were the same with and without patients with TIA.

We found no evidence that the effects of risk factors differed by sex, age, or educational level; however, we noted significant differences in their effects on cognitive function between whites, Koreans, and Chinese, suggesting that risk factors may have a variable influence on cognition in different ethnoracial groups. Some studies have identified racial differences in dementia risk in American communities in association with certain vascular risk factors, ${ }^{25,26}$ yet the literature on interethnic differences across geographic regions is extremely limited.

Our analyses that included controls suggested that, while hypertension, diabetes mellitus, $\mathrm{AF}$, and smoking were associated with poorer cognition after stroke, the nature of those associations was not different in participants without stroke. This indicates that prevention methods used in stroke and stroke-free populations regarding these risk factors could lead to similar outcomes, although the efficacy of those interventions could differ between those 2 groups.

Despite our studies having different inclusion/exclusion criteria and being geographically diverse, the heterogeneity in the risk factor analyses is generally low, and the prevalences of cognitive impairment are comparable across studies, except for slightly higher proportions observed in SAM. This may have been the result of SAM being an older study that used a comparison group that, with only 38 participants, might not have been a truly representative normative sample.

Strengths of our study include the operationalized definition of cognitive impairment, the standardization of data across diverse international cohorts, and the more detailed and robust findings that arise from IPD meta-analyses. Our study also has several limitations, some of which apply to poststroke studies in general. First, patients with cognitive impairment might be less willing or able to participate, and individuals with severe language impairment or those who are very ill are generally excluded, leading to some selection bias. Second, there is no consensus on the allocation of neuropsychological tests into domains because neuropsychological tests are 
multifactorial and therefore domains may overlap. Third, some studies have only 1 test per domain, making the domain scores less reliable. Fourth, the standardization of test scores relies on the assumption that the comparison group used for a particular study is representative of its patient group and of adequate size; thus, the domain scores and proportions of impairment could be biased by the nature of the comparison group. Fifth, risk factor history was generally based on medical record review, and there could have been differences in how it was recorded across studies. Sixth, while the inclusion of MRI data would have permitted a more rigorous examination of the relationship between stroke characteristics and PSCI, MRI was performed on only a subset of patients, and the harmonization of imaging data would have been beyond the scope of the present study. Finally, 3 studies in our combined analyses did not attempt to exclude patients with known dementia, but all studies may have included some patients with preexisting dementia because no clinical assessments were performed until after the index stroke and patient recruitment, which could have led to overestimation of the frequency of cognitive impairment.

Despite those limitations, we believe that this work presents a robust analysis that draws on the strengths of the contributing studies and provides valuable information on stroke as a basis for cognitive impairment.

\section{Study funding}

This work was supported by the Vincent Fairfax Family Foundation (Australia) and the National Health and Medical Research Council of Australia Program Grant. Funding information for individual studies is available from Dryad (appendix T20, doi.org/10.5061/dryad.m517990).

\section{Disclosure}

J. Lo reports grants from Vincent Fairfax. J. Crawford and D. Desmond report no disclosures relevant to the manuscript. O. Godefroy reports grants from DGOS French (health department). H. Jokinen reports grants from the Clinical Research Institute and the Medical Research Fund of the Helsinki University Hospital. S. Mahinrad, H. Bae, J. Lim, S. Köhler, E. Douven, and J. Staals report no disclosures relevant to the manuscript. C. Chen reports grants from National Medical Research Council of Singapore during the conduct of the study. X. Xu, E. Chong, R. Akinyemi, R. Kalaria, A. Ogunniyi, M. Barbay, M. Roussel, B. Lee, V. Srikanth, C. Moran, N. Kandiah, R. Chander, B. Sabayan, J. Jukema, S. Melkas, T. Erkinjuntti, H. Brodaty, R. Bordet, S. Bombois, H. Hénon, and D. Lipnicki report no disclosures relevant to the manuscript. N. Kochan reports grants from National Health and Medical Research Council Early Career Fellowship (RG123148). P. Sachdev is on the Advisory Board of Biogen Australia. Go to Neurology.org/N for full disclosures.

\section{Publication history}

Received by Neurology September 16, 2018. Accepted in final form July 26, 2019.

\section{Appendix 1 Authors}

\begin{tabular}{|c|c|c|c|}
\hline Name & Location & Role & Contribution \\
\hline $\begin{array}{l}\text { Jessica W. Lo, } \\
\text { MSc }\end{array}$ & $\begin{array}{l}\text { University of New } \\
\text { South Wales, } \\
\text { Sydney, Australia }\end{array}$ & Author & $\begin{array}{l}\text { Design of study } \\
\text { methods; analyzed } \\
\text { and interpreted the } \\
\text { data; drafted and } \\
\text { substantially } \\
\text { revised the } \\
\text { manuscript for } \\
\text { intellectual content }\end{array}$ \\
\hline $\begin{array}{l}\text { John D. } \\
\text { Crawford, } \\
\text { PhD }\end{array}$ & $\begin{array}{l}\text { University of New } \\
\text { South Wales, } \\
\text { Sydney, Australia }\end{array}$ & Author & $\begin{array}{l}\text { Design and } \\
\text { conceptualized study } \\
\text { and methods; } \\
\text { interpreted the data; } \\
\text { and revised the } \\
\text { manuscript for } \\
\text { intellectual content }\end{array}$ \\
\hline $\begin{array}{l}\text { David W. } \\
\text { Desmond, } \\
\text { PhD }\end{array}$ & US & Author & $\begin{array}{l}\text { Major role in the } \\
\text { acquisition of data; } \\
\text { substantially revised } \\
\text { the manuscript for } \\
\text { intellectual content }\end{array}$ \\
\hline $\begin{array}{l}\text { Olivier } \\
\text { Godefroy, } \\
\text { MD }\end{array}$ & $\begin{array}{l}\text { University Hospital } \\
\text { of Amiens, France }\end{array}$ & Author & $\begin{array}{l}\text { Major role in the } \\
\text { acquisition of data; } \\
\text { revised the manuscript } \\
\text { for intellectual content }\end{array}$ \\
\hline $\begin{array}{l}\text { Hanna } \\
\text { Jokinen, PhD }\end{array}$ & $\begin{array}{l}\text { University of } \\
\text { Helsinki and } \\
\text { Helsinki University } \\
\text { Hospital, Finland }\end{array}$ & Author & $\begin{array}{l}\text { Major role in the } \\
\text { acquisition of data and } \\
\text { analysis of data and } \\
\text { revised the manuscript } \\
\text { for intellectual content }\end{array}$ \\
\hline $\begin{array}{l}\text { Simin } \\
\text { Mahinrad, } \\
\text { MD }\end{array}$ & $\begin{array}{l}\text { Leiden University } \\
\text { Medical Center, the } \\
\text { Netherlands }\end{array}$ & Author & Analysis of data \\
\hline $\begin{array}{l}\text { Hee-Joon } \\
\text { Bae, MD }\end{array}$ & $\begin{array}{l}\text { Seoul National } \\
\text { University School of } \\
\text { Medicine, Republic } \\
\text { of Korea }\end{array}$ & Author & $\begin{array}{l}\text { Major role in the } \\
\text { acquisition of data }\end{array}$ \\
\hline $\begin{array}{l}\text { Jae-Sung } \\
\text { Lim, MD }\end{array}$ & $\begin{array}{l}\text { Hallym University } \\
\text { Sacred Heart } \\
\text { Hospital, Republic } \\
\text { of Korea }\end{array}$ & Author & $\begin{array}{l}\text { Major role in the } \\
\text { acquisition of data }\end{array}$ \\
\hline $\begin{array}{l}\text { Sebastian } \\
\text { Köhler, PhD }\end{array}$ & $\begin{array}{l}\text { Maastricht } \\
\text { University, the } \\
\text { Netherlands }\end{array}$ & Author & $\begin{array}{l}\text { Major role in the } \\
\text { acquisition of data; } \\
\text { contributed to revising } \\
\text { manuscript for } \\
\text { intellectual content }\end{array}$ \\
\hline $\begin{array}{l}\text { Elles } \\
\text { Douven, PhD }\end{array}$ & $\begin{array}{l}\text { Maastricht } \\
\text { University, the } \\
\text { Netherlands }\end{array}$ & Author & $\begin{array}{l}\text { Major role in the } \\
\text { acquisition of data }\end{array}$ \\
\hline $\begin{array}{l}\text { Julie Staals, } \\
\text { MD }\end{array}$ & $\begin{array}{l}\text { Maastricht } \\
\text { University Medical } \\
\text { Center, the } \\
\text { Netherlands }\end{array}$ & Author & $\begin{array}{l}\text { Major role in the } \\
\text { acquisition of data }\end{array}$ \\
\hline $\begin{array}{l}\text { Christopher } \\
\text { Chen, MD }\end{array}$ & $\begin{array}{l}\text { National University } \\
\text { of Singapore }\end{array}$ & Author & $\begin{array}{l}\text { Major role in the } \\
\text { acquisition of data }\end{array}$ \\
\hline Xin Xu, PhD & $\begin{array}{l}\text { National University } \\
\text { of Singapore }\end{array}$ & Author & $\begin{array}{l}\text { Major role in the } \\
\text { acquisition of data }\end{array}$ \\
\hline $\begin{array}{l}\text { Eddie J. } \\
\text { Chong, BA }\end{array}$ & $\begin{array}{l}\text { National University } \\
\text { of Singapore }\end{array}$ & Author & $\begin{array}{l}\text { Major role in the } \\
\text { acquisition of data }\end{array}$ \\
\hline $\begin{array}{l}\text { Rufus } 0 . \\
\text { Akinyemi, } \\
\text { PhD }\end{array}$ & $\begin{array}{l}\text { University of } \\
\text { Ibadan, Nigeria }\end{array}$ & Author & $\begin{array}{l}\text { Major role in the } \\
\text { acquisition of data }\end{array}$ \\
\hline
\end{tabular}


Appendix 1 (continued)

\begin{tabular}{|c|c|c|c|}
\hline Name & Location & Role & Contribution \\
\hline $\begin{array}{l}\text { Rajesh N. } \\
\text { Kalaria, } \\
\text { FRCPath }\end{array}$ & $\begin{array}{l}\text { Newcastle } \\
\text { University, } \\
\text { Newcastle Upon } \\
\text { Avon, UK }\end{array}$ & Author & $\begin{array}{l}\text { Major role in the } \\
\text { acquisition of data }\end{array}$ \\
\hline $\begin{array}{l}\text { Adesola } \\
\text { Ogunniyi, } \\
\text { FRCP }\end{array}$ & $\begin{array}{l}\text { University of } \\
\text { Ibadan, Nigeria }\end{array}$ & Author & $\begin{array}{l}\text { Major role in the } \\
\text { acquisition of data }\end{array}$ \\
\hline $\begin{array}{l}\text { Mélanie } \\
\text { Barbay, MD }\end{array}$ & $\begin{array}{l}\text { University Hospital } \\
\text { of Amiens, France }\end{array}$ & Author & $\begin{array}{l}\text { Major role in the } \\
\text { acquisition of data }\end{array}$ \\
\hline $\begin{array}{l}\text { Martine } \\
\text { Roussel, PhD }\end{array}$ & $\begin{array}{l}\text { University Hospital } \\
\text { of Amiens, France }\end{array}$ & Author & $\begin{array}{l}\text { Major role in the } \\
\text { acquisition of data }\end{array}$ \\
\hline $\begin{array}{l}\text { Byung-Chul } \\
\text { Lee, MD }\end{array}$ & $\begin{array}{l}\text { Hallym University } \\
\text { Sacred Heart } \\
\text { Hospital, Republic } \\
\text { of Korea }\end{array}$ & Author & $\begin{array}{l}\text { Major role in the } \\
\text { acquisition of data }\end{array}$ \\
\hline $\begin{array}{l}\text { Velandai K. } \\
\text { Srikanth, } \\
\text { PhD }\end{array}$ & $\begin{array}{l}\text { Monash University, } \\
\text { Melbourne, } \\
\text { Australia }\end{array}$ & Author & $\begin{array}{l}\text { Major role in the } \\
\text { acquisition of data }\end{array}$ \\
\hline $\begin{array}{l}\text { Christopher } \\
\text { Moran, PhD }\end{array}$ & $\begin{array}{l}\text { Monash University, } \\
\text { Melbourne, } \\
\text { Australia }\end{array}$ & Author & $\begin{array}{l}\text { Major role in the } \\
\text { acquisition of data }\end{array}$ \\
\hline $\begin{array}{l}\text { Nagaendran } \\
\text { Kandiah, } \\
\text { FRCP }\end{array}$ & $\begin{array}{l}\text { National } \\
\text { Neuroscience } \\
\text { Institute, Singapore }\end{array}$ & Author & $\begin{array}{l}\text { Major role in the } \\
\text { acquisition of data }\end{array}$ \\
\hline $\begin{array}{l}\text { Russell J. } \\
\text { Chander, BA }\end{array}$ & $\begin{array}{l}\text { University of New } \\
\text { South Wales, } \\
\text { Sydney, Australia }\end{array}$ & Author & $\begin{array}{l}\text { Major role in the } \\
\text { acquisition of data }\end{array}$ \\
\hline $\begin{array}{l}\text { Behnam } \\
\text { Sabayan, MD }\end{array}$ & $\begin{array}{l}\text { Leiden University } \\
\text { Medical Center, the } \\
\text { Netherlands }\end{array}$ & Author & $\begin{array}{l}\text { Major role in the } \\
\text { acquisition of data }\end{array}$ \\
\hline $\begin{array}{l}\text { J. Wouter } \\
\text { Jukema, MD }\end{array}$ & $\begin{array}{l}\text { Leiden University } \\
\text { Medical Center, the } \\
\text { Netherlands }\end{array}$ & Author & $\begin{array}{l}\text { Major role in the } \\
\text { acquisition of data }\end{array}$ \\
\hline $\begin{array}{l}\text { Susanna } \\
\text { Melkas, MD }\end{array}$ & $\begin{array}{l}\text { University of } \\
\text { Helsinki and } \\
\text { Helsinki University } \\
\text { Hospital, Finland }\end{array}$ & Author & $\begin{array}{l}\text { Major role in the } \\
\text { acquisition of data }\end{array}$ \\
\hline $\begin{array}{l}\text { Timo } \\
\text { Erkinjuntti, } \\
\text { MD }\end{array}$ & $\begin{array}{l}\text { University of } \\
\text { Helsinki and } \\
\text { Helsinki University } \\
\text { Hospital, Finland }\end{array}$ & Author & $\begin{array}{l}\text { Major role in the } \\
\text { acquisition of data }\end{array}$ \\
\hline $\begin{array}{l}\text { Henry } \\
\text { Brodaty, MD }\end{array}$ & $\begin{array}{l}\text { University of New } \\
\text { South Wales, } \\
\text { Sydney, Australia }\end{array}$ & Author & $\begin{array}{l}\text { Major role in the } \\
\text { acquisition of data and } \\
\text { contributed to the } \\
\text { revision of manuscript } \\
\text { for intellectual content }\end{array}$ \\
\hline $\begin{array}{l}\text { Régis } \\
\text { Bordet, MD }\end{array}$ & $\begin{array}{l}\text { University of Lille, } \\
\text { France }\end{array}$ & Author & $\begin{array}{l}\text { Major role in the } \\
\text { acquisition of data }\end{array}$ \\
\hline $\begin{array}{l}\text { Stéphanie } \\
\text { Bombois, } \\
\text { MD }\end{array}$ & $\begin{array}{l}\text { University of Lille, } \\
\text { France }\end{array}$ & Author & $\begin{array}{l}\text { Major role in the } \\
\text { acquisition of data }\end{array}$ \\
\hline $\begin{array}{l}\text { Hilde Hénon, } \\
\text { MD }\end{array}$ & $\begin{array}{l}\text { University of Lille, } \\
\text { France }\end{array}$ & Author & $\begin{array}{l}\text { Major role in the } \\
\text { acquisition of data }\end{array}$ \\
\hline $\begin{array}{l}\text { Darren M. } \\
\text { Lipnicki, PhD }\end{array}$ & $\begin{array}{l}\text { University of New } \\
\text { South Wales, } \\
\text { Sydney, Australia }\end{array}$ & Author & $\begin{array}{l}\text { Design of study } \\
\text { methods and } \\
\text { contributed to revising } \\
\text { manuscript for } \\
\text { intellectual content }\end{array}$ \\
\hline
\end{tabular}

Appendix 1 (continued)

\begin{tabular}{|c|c|c|c|}
\hline Name & Location & Role & Contribution \\
\hline $\begin{array}{l}\text { Nicole A. } \\
\text { Kochan, PhD }\end{array}$ & $\begin{array}{l}\text { University of New } \\
\text { South Wales, } \\
\text { Sydney, Australia }\end{array}$ & Author & $\begin{array}{l}\text { Design of study } \\
\text { methods and } \\
\text { contributed to revising } \\
\text { manuscript for } \\
\text { intellectual content }\end{array}$ \\
\hline $\begin{array}{l}\text { Perminder S. } \\
\text { Sachdev, MD }\end{array}$ & $\begin{array}{l}\text { University of New } \\
\text { South Wales, } \\
\text { Sydney, Australia }\end{array}$ & Author & $\begin{array}{l}\text { Design and } \\
\text { conceptualized study } \\
\text { and methods; } \\
\text { interpreted the data; } \\
\text { drafted and } \\
\text { substantially revised } \\
\text { the manuscript for } \\
\text { intellectual content }\end{array}$ \\
\hline
\end{tabular}

Appendix 2 Co-investigators from the STROKOG Collaboration

\begin{tabular}{|c|c|c|c|}
\hline Name & Location & Role & Contribution \\
\hline $\begin{array}{l}\text { Amy } \\
\text { Brodtmann, } \\
\text { PhD }\end{array}$ & $\begin{array}{l}\text { University of } \\
\text { Melbourne, } \\
\text { Australia }\end{array}$ & $\begin{array}{l}\text { Research } \\
\text { Scientific } \\
\text { Committee } \\
\text { member }\end{array}$ & $\begin{array}{l}\text { Reviewed and } \\
\text { approved project } \\
\text { proposal }\end{array}$ \\
\hline $\begin{array}{l}\text { Aleksandra } \\
\text { Klimkowicz- } \\
\text { Mrowiec, } \\
\text { MD }\end{array}$ & $\begin{array}{l}\text { Jagiellonian } \\
\text { University } \\
\text { Medical College, } \\
\text { Kraków Poland }\end{array}$ & $\begin{array}{l}\text { Research } \\
\text { Scientific } \\
\text { Committee } \\
\text { member }\end{array}$ & $\begin{array}{l}\text { Reviewed, approved } \\
\text { project proposal and } \\
\text { contributed data } \\
\text { from cohort }\end{array}$ \\
\hline $\begin{array}{l}\text { Martin } \\
\text { Dichgans, } \\
\text { MD }\end{array}$ & $\begin{array}{l}\text { Ludwig- } \\
\text { Maximilians- } \\
\text { University, } \\
\text { Munich, } \\
\text { Germany }\end{array}$ & $\begin{array}{l}\text { Research } \\
\text { Scientific } \\
\text { Committee } \\
\text { member }\end{array}$ & $\begin{array}{l}\text { Reviewed and } \\
\text { approved project } \\
\text { proposal }\end{array}$ \\
\hline $\begin{array}{l}\text { Michael } \\
\text { Hoffmann, } \\
\text { MD }\end{array}$ & $\begin{array}{l}\text { University of } \\
\text { Central Florida, } \\
\text { Orlando }\end{array}$ & $\begin{array}{l}\text { Research } \\
\text { Scientific } \\
\text { Committee } \\
\text { member }\end{array}$ & $\begin{array}{l}\text { Reviewed and } \\
\text { approved project } \\
\text { proposal }\end{array}$ \\
\hline $\begin{array}{l}\text { Thomas } \\
\text { Linden, MD }\end{array}$ & $\begin{array}{l}\text { University of } \\
\text { Gothenburg, } \\
\text { Sweden }\end{array}$ & $\begin{array}{l}\text { Research } \\
\text { Scientific } \\
\text { Committee } \\
\text { member }\end{array}$ & $\begin{array}{l}\text { Reviewed and } \\
\text { approved project } \\
\text { proposal }\end{array}$ \\
\hline $\begin{array}{l}\text { Joanna } \\
\text { Wardlaw, } \\
\text { MD }\end{array}$ & $\begin{array}{l}\text { University of } \\
\text { Edinburgh, UK }\end{array}$ & $\begin{array}{l}\text { Research } \\
\text { Scientific } \\
\text { Committee } \\
\text { member }\end{array}$ & $\begin{array}{l}\text { Reviewed, approved } \\
\text { project proposal and } \\
\text { contributed data } \\
\text { from cohort }\end{array}$ \\
\hline $\begin{array}{l}\text { Charlotte } \\
\text { Cordonnier, } \\
\text { MD }\end{array}$ & $\begin{array}{l}\text { University of } \\
\text { Lille, France }\end{array}$ & $\begin{array}{l}\text { Research } \\
\text { Scientific } \\
\text { Committee } \\
\text { member }\end{array}$ & $\begin{array}{l}\text { Reviewed, approved } \\
\text { project proposal }\end{array}$ \\
\hline $\begin{array}{l}\text { Vincent } \\
\text { Mok, MD }\end{array}$ & $\begin{array}{l}\text { Chinese } \\
\text { University of } \\
\text { Hong Kong, } \\
\text { Hong Kong }\end{array}$ & $\begin{array}{l}\text { Research } \\
\text { Scientific } \\
\text { Committee } \\
\text { member }\end{array}$ & $\begin{array}{l}\text { Reviewed, approved } \\
\text { project proposal and } \\
\text { contributed data } \\
\text { from cohort }\end{array}$ \\
\hline
\end{tabular}

\section{References}

1. Pendlebury ST, Rothwell PM. Prevalence, incidence, and factors associated with prestroke and post-stroke dementia: a systematic review and meta-analysis. Lancet Neurol 2009;8:1006-1018.

2. O'Brien JT, Erkinjuntti T, Reisberg B, et al. Vascular cognitive impairment. Lancet Neurol 2003;2:89-98. 
3. Looi JC, Sachdev PS. Differentiation of vascular dementia from AD on neuropsychological tests. Neurology 1999;53:670-678.

4. Sachdev PS, Brodaty H, Valenzuela MJ, et al. The neuropsychological profile of vascular cognitive impairment in stroke and TIA patients. Neurology 2004;62: 912-919.

5. Gottesman RF, Hills AE. Predictors and assessment of cognitive dysfunction resulting from ischaemic stroke. Lancet Neurol 2010;9:895-905.

6. Sposato LA, Kapral MK, Fang J, et al. Declining incidence of stroke and dementia: coincidence or prevention opportunity? JAMA Neurol 2015;72: 1529-1531.

7. Gorelick PB, Scuteri A, Black SE, et al. Vascular contributions to cognitive impairment and dementia: a statement for healthcare professionals from the American Heart Association/American Stroke Association. Stroke 2011;42:2672-2713.

8. Sachdev PS, Lo JW, Crawford JD, et al. STROKOG (Stroke and Cognition Consortium): an international consortium to examine the epidemiology, diagnosis, and treatment of neurocognitive disorders in relation to cerebrovascular disease. Alzheimers Dement (Amst) 2017;7:11-23.

9. Griffith L, van den Heuvel E, Fortier I, et al. Harmonization of cognitive measures in individual participant data and aggregate data meta-analysis. In: Methods Research Reports. Rockville: Agency for Healthcare Research and Quality; 2013.

10. Godefroy O, Gibbons L, Diouf M, et al. Validation of an integrated method for determining cognitive ability: implications for routine assessments and clinical trials. Cortex 2014;54:51-62.

11. Lezak MD, Howieson DB, Loring DW. Neuropsychological Assessment, 4th ed. New York: Oxford University Press; 2004.

12. Sachdev PS, Lipnicki DM, Kochan NA, et al. The prevalence of mild cognitive impairment in diverse geographical and ethnocultural regions: the COSMIC Collaboration. PLoS One 2015;10:e0142388.

13. Debray TP, Moons KG, van Valkenhoef G, et al. Get real in individual participant data (IPD) meta-analysis: a review of the methodology. Res Synth Methods 2015;6: 293-309.

14. Baron RM, Kenny DA. The moderator-mediator variable distinction in social psychological research: conceptual, strategic, and statistical considerations. J Pers Soc Psychol 1986;51:1173-1182.
15. Higgins JP, Thompson SG, Deeks JJ, Altman DG. Measuring inconsistency in metaanalyses. BMJ 2003;327:557-560.

16. Stewart LA, Clarke M, Rovers M, et al. Preferred Reporting Items for a Systematic Review and Meta-Analysis of individual participant data. JAMA 2015;313: 1657-1665.

17. Makin SD, Turpin S, Dennis MS, Wardlaw JM. Cognitive impairment after lacunar stroke: systematic review and meta-analysis of incidence, prevalence and comparison with other stroke subtypes. J Neurol Neurosurg Psychiatry 2013;84: 893-900.

18. Kennelly SP, Lawlor BA, Kenny RA. Blood pressure and dementia: a comprehensive review. Ther Adv Neurol Disord 2009;2:241-260.

19. Köhler S, Baars MAE, Spauwen P, Schievink S, Verhey FRJ, van Boxtel MJP. Temporal evolution of cognitive changes in incident hypertension: prospective cohort study across the adult age span. Hypertension 2014;63:245-251.

20. Iadecola C, Yaffe K, Biller J, et al. Impact of hypertension on cognitive function: a scientific statement from the American Heart Association. Hypertension 2016;68: e67-94.

21. Zhong G, Wang Y, Zhang Y, Guo JJ, Zhao Y. Smoking is associated with an increased risk of dementia: a meta-analysis of prospective cohort studies with investigation of potential effect modifiers. PLoS One 2015;10:e118333.

22. Kalantarian S, Stern TA, Mansour M, Ruskin JN. Cognitive impairment associated with atrial fibrillation: a meta-analysis. Ann Intern Med 2013;158: $338-346$.

23. Deckers K, Schievink SHJ, Rodriquez MMF, et al. Coronary heart disease and risk for cognitive impairment or dementia: systematic review and meta-analysis. PLoS One 2017;12:e0184244.

24. van Rooij FG, Schaapsmeerders P, Maaijwee NAM, et al. Persistent cognitive impairment after transient ischemic attack. Stroke 2014;45:2270-2274.

25. Mayeda ER, Karter AJ, Huang ES, Moffet HH, Haan MN, Whitmer RA. Racial/ ethnic differences in dementia risk among older type 2 diabetic patients: the Diabetes and Aging Study. Diabetes Care 2014;37:1009-1015.

26. Luchsinger JA, Tang MX, Stern Y, Shea S, Mayeux R. Diabetes mellitus and risk of Alzheimer's disease and dementia with stroke in a multiethnic cohort. Am J Epidemiol 2001;154:635-641. 


\section{Neurology}

\section{Profile of and risk factors for poststroke cognitive impairment in diverse ethnoregional groups}

Jessica W. Lo, John D. Crawford, David W. Desmond, et al.

Neurology 2019;93;e2257-e2271 Published Online before print November 11, 2019

DOI 10.1212/WNL.0000000000008612

This information is current as of November 11, 2019

\section{Updated Information \&} Services

References

Citations

Subspecialty Collections

Permissions \& Licensing

\section{Reprints}

including high resolution figures, can be found at: http://n.neurology.org/content/93/24/e2257.full

This article cites 24 articles, 7 of which you can access for free at: http://n.neurology.org/content/93/24/e2257.full\#ref-list-1

This article has been cited by 2 HighWire-hosted articles: http://n.neurology.org/content/93/24/e2257.full\#\#otherarticles

This article, along with others on similar topics, appears in the following collection(s):

MCI (mild cognitive impairment)

http://n.neurology.org/cgi/collection/mci_mild_cognitive_impairment

Prevalence studies

http://n.neurology.org/cgi/collection/prevalence_studies

Risk factors in epidemiology

http://n.neurology.org/cgi/collection/risk_factors_in_epidemiology Vascular dementia

http://n.neurology.org/cgi/collection/vascular_dementia

Information about reproducing this article in parts (figures,tables) or in its entirety can be found online at:

http://www.neurology.org/about/about_the_journal\#permissions

Information about ordering reprints can be found online:

http://n.neurology.org/subscribers/advertise

Neurology ${ }^{\circledR}$ is the official journal of the American Academy of Neurology. Published continuously since 1951, it is now a weekly with 48 issues per year. Copyright Copyright @ 2019 The Author(s). Published by Wolters Kluwer Health, Inc. on behalf of the American Academy of Neurology.. All rights reserved. Print ISSN: 0028-3878. Online ISSN: 1526-632X.

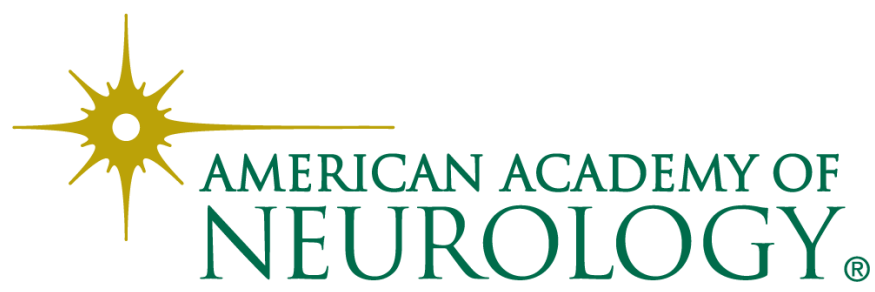

